\title{
Studies of the Biochemical Effects of Arsenic Content of Carbide Induced Ripe Banana Fruit in the Rat
}

\author{
OTITE-DOUGLAS, M. I and FADAIRO, E. A \\ Industrial Safety and Environmental Technology Department, Petroleum Training Institute Effurun, \\ PMB 20 Effurun, Delta state, Nigeria. \\ *Corresponding author E-mail: Fadairo_e@ @pti.edu.ng; otitedouglas_mo@pti.edu.ng \\ http://dx.doi.org/10.13005/ojc/350412
}

(Received: June 06, 2019; Accepted: July 17, 2019)

\begin{abstract}
Arsenic is a well-known poison and it is found in trace amount in calcium carbide use for welding purposes and secondarily use by farmers and traders in Warri Metropolis to induce ripening processes in foods. This study was designed to evaluate the concentration of arsenic in selected banana fruits within Warri Metropolis. It was also designed to determine its effects on some key biochemical indices of toxicity. The atomic absorption method was used to determine arsenic content of fruits and the biochemical indices evaluated were liver body weight ratio, body weight gain, the extent of lipid peroxidation in the liver organ and plasma, and the activities of alkaline phosphatases in the plasma and liver. Results showed a high concentration of arsenic in carbide-induced ripe banana (CTB) with an average value of $0.11 \mathrm{mg} / \mathrm{kg}$ wet mass of test banana relative to the carbide-free banana (CFB) control with a value of $<0.001 \mathrm{mg} / \mathrm{kg}$. Our findings also showed a slight increase in body weight and decrease in liver body weight ratio of CTB rats, but the changes were not significant $\mathrm{P}>0.05$ when compared to the control $(C F B)$. However, there was a significant $(P<0.05)$ decrease in body weight and increase in organ body weight ratios of arsenic-only exposed rats relative to the control. The activities of alkaline phosphatase in plasma increased significantly $(P<0.05)$ for the groups of rats exposed to CTB and arsenic only via feed relative to their respective controls. The plasma and liver malondialdehyde (MDA) levels of rats exposed to CTB and arsenic only via feed were also elevated in this present study when compared to their respective controls however, the levels were not significant $(P>0.05)$. This study shows the possibility of Plasma -ALP alteration and changes in levels of tissue lipid peroxidation products of carbide -treated ripe banana fruits. There is therefore the need for an urgent regulation on the use of carbide in the induction of ripening of fruits.
\end{abstract}

Keyword: Biochemical effects, Arsenic, Calcium carbide, Banana fruits, The rat.

INTRODUCTION

In order to hasten the ripening of fruits in developing countries like Nigeria, Cameroon, Ghana, Bangladesh, India, and Pakistan, Chemical substances are added ${ }^{4}$. One of such substance is calcium carbide $\left(\mathrm{CaC}_{2}\right)$, also known as calcium acetylide. It is used industrially for welding and other processes and secondarily by farmers and traders to induce ripening in fruits like citrus, banana and plantain in Warri Metropolis through a mechanism speculated to be related to the production of

This is an Open Access article licensed under a Creative Commons license: Attribution 4.0 International (CC- BY). Published by Oriental Scientific Publishing Company @ 2018

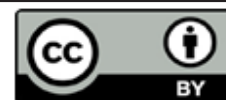


acetylene and subsequently ethylene. Calcium carbide is considered very hazardous as a food processing agent because it contains traces of the heavy metal, arsenic ${ }^{4}$. Reports show sources of arsenic in foods to include exposure to arsenical pesticide and methods used in processing and preparation ${ }^{7,25}$. Exposure to arsenic through banana is speculated in our present study because the fruits are eaten as ripe banana without the contemplation of washing before consumption. Arsenic is an element of concern because of its toxicological significance, even at low concentration ${ }^{19}$. Arsenic is classified as group 1 human carcinogen (International Agency for Research on Cancer ${ }^{10,11}$ and has been implicated in health incidences involving damage to chromosomes, induce spontaneous abortion, congenital malformations due to placental transfer of the element, reduce birth weight, disturb normal liver, kidney and CNS function and a known cause of lung cancer ${ }^{11,12,16,17}$ even at relatively very low chronic exposures. A number of studies have shown that food rather than water are responsible for majority of incidences of arsenic poisoning as inorganic arsenic. . $^{14,15,26,27}$ There are reports suggesting that most of the arsenic in food is organic and therefore non-toxic. ${ }^{22,27}$ Though there are contrary evidences demonstrating that organic arsenic concentration is only high in sea foods while the inorganic arsenic is higher in non-sea foods. ${ }^{11}$

Many researches have been carried out using enzymes as indicators of cell injury, the use of alkaline phosphatase as cell injury indicator is not very common. This study was therefore undertaken in order to provide a clear understanding of the possible molecular changes responsible for the bio effects of arsenic outlined above using alkaline phosphatases activities and lipid peroxidation products as indicators of liver cell injury.

\section{MATERIALS AND METHODS}

\section{Study area and sample collection}

Yellow ripe banana fruits were bought from Ugborikoko and Main Market in Warri, Delta State Nigeria on one hand. Another set of matured but unripe banana fruits were collected from a garden located in Warri South Local Government Area with permission from the owner for use as control and in the pilot study. $100 \mathrm{mg} / \mathrm{g}$ of carbide was used to induce ripening of banana harvested directly from the farm in the laboratory. The control well matured but unripe banana fruits, harvested from a garden in Warri with farmer's permission, were not pre-treated with carbide, but were subjected to the same environmental ripening conditions for 72 hours. The arsenic content of the various banana fruits were determined after 72 hours. In Phase II of study, the estimated arsenic content of the various banana fruits were used to treat the respective rat groups via feed. Rats in group I were maintained on carbide and arsenic-free banana diet (control) respectively. While rats in groups II and III were treated with carbide exposed banana (CTB-2) and laboratory reconstituted arsenic (CTB-2 arsenic concentration) diet designated as (arsenic only) respectively.

\section{Sample preparation}

5 gram of the control samples were washed with deionized water, chopped into pieces and dried in the furnace at $105^{\circ} \mathrm{C}$ to ash. The test banana samples were also subjected to the same procedure as above. At the end of the treatment period, the samples were treated with mixed acid solution containing $\mathrm{HNO}_{3}: \mathrm{HClO}$ in the ratio $(4: 1)$ and subjected to heating until solution was homogenous. The samples were then filtered into a $100 \mathrm{ml}$ volumetric flask using a Whatman cellulose (no 44) filters (paper) with a retentivity of 1 (microns) and of slow speed, and the volume was made up to $100 \mathrm{ml}$ and kept until ready for atomic absorption spectrophometric (AAS) analysis. The concentration of arsenic determined by AAS was used to formulate feed for the rats in the second phase of study as follows.

\section{Determination of Arsenic in banana samples}

Arsenic content of the banana fruit was determined by the atomic absorption spectrophotometric method with vaporization assembly described by ${ }^{3}$. This involved reduction of arsenic oxidation state to free arsenic atom thereby allowing its detection by the AAS.

\section{Treatment of Animals}

Treatment and management of animals were done according to the rules of local ethics committee of the Faculty of Life Sciences, University of Benin and in accordance with the Principles of Laboratory Animal Care (NIH publication no. 85-93, revised 1998). The concentrations of arsenic used were calculated on the basis of average banana arsenic concentrations of banana fruits in Warri as 
determined by atomic absorption spectrophotometer at the time of this study. A total of fifteen adult rats with $132 \pm 5 \mathrm{~g}$ (mean weight) were used for this phase of study. They were allowed water and food ad libitum and allowed seven to acclimatize) to the laboratory conditions before commencement of study. The rats were divided into three groups of five rats each. Group I rats designated as the control were maintained on carbide and arsenic free diet. Group 2 designated as CTB was maintained on feed formulated with carbide-induced ripe banana bought from Ogborikoko Market, Warri. While, group 3 rats designated as arsenic only were maintained on feed formulated from arsenic salt calculated from AAS determined concentrations of arsenic of market carbide-induced ripe banana fruits designated as (CTB-2)(representing the average concentrations of arsenic content of Warri Metropolis banana) for $28 \mathrm{~d}$.

\section{Preparation of whole blood for alkaline phosphatases assays $^{24}$.}

$5 \mathrm{ml}$ whole blood was centrifuge at 3000 rpm for 5 minutes. The plasma was collected, stored in a refrigerator $\left(-18^{\circ} \mathrm{C}\right)$ and analyzed within $24 \mathrm{~h}$ of collection.

\section{Preparation of blood and tissue homogenate for malondialdehyde $\mathrm{e}^{20}$}

A weighed portion of the liver was homogenized in ice cold normal saline to obtain a $20 \%$ homogenate $(1: 4 \mathrm{w} / \mathrm{v})$. The homogenate was centrifuge at $2000 \mathrm{xg}$ for $10 \mathrm{~min}$ and the supernatant was used for the determination of liver malondialdehyde level and liver alkaline phosphatase activities.

\section{Biochemical Assays}

Body weight changes and organ body weight ratios were determined by the method outlined $b^{6}{ }^{6}$. The difference between the pre-study and final body weight (in g) at the end of the $90 \mathrm{~d}$ study period was considered as the body weight change while the weight of organ at the end of the study period divided by the final body weight of the rat was used as the brain body weight ratio. The activities of alkaline and acid phosphatases were determined in plasma by the method of Kind and King (1954) modified by ${ }^{23}$. Alkaline and acid phosphatases at an alkaline or acid $\mathrm{pH}$ respectively hydrolysed di sodium phenylphosphate to form phenol. The phenol formed reacts with 4-aminoantipyrine in the presence of potassium ferricyanide, as an oxidizing agent, to form a red coloured complex. The intensity of the colour formed is directly proportional to the activity of the respective phosphatases in the plasma sample.

The levels of lipid peroxidation products determined as malondialdehyde $n$ the liver tissue homogenate brain tissue homogenate supernatant were evaluated by the method of ${ }^{8}$. The procedure involves the determination of thiobarbituric reactive substances (TBARs) which are indicators of lipid peroxidation. Values for TBARs are reported as malondialdehyde (MDA) quantified using a molar extinction coefficient of $1.5 \times 10^{5} \mathrm{M}^{-1} \mathrm{~cm}^{-1}$ and expressed as micromole MDA per gram weight of tissue. Each unit represents one micromole of MDA.

Table 1: Composition of test and control diets of rats

\begin{tabular}{clccc}
\hline S/no & Composition & $\begin{array}{c}\text { Control } \\
\text { diet }\end{array}$ & $\begin{array}{c}\text { Test diet } \\
1(\mathrm{~g})\end{array}$ & $\begin{array}{c}\text { Test diet } \\
2(\mathrm{~g})\end{array}$ \\
\hline 1 & $\begin{array}{l}\text { Carbide free } \\
\text { banana }\end{array}$ & 20 & - & 20 \\
2 & Carbide-exposed & - & 20 & 0 \\
& banana (powder) & & & \\
3 & Arsenic salt & - & - & $0.18 \mathrm{ppm}$ \\
4 & Growers mash & 50 & 50 & 50 \\
5 & Ferobin plus & 2 & 2 & 2 \\
& (multivitamin tablet) & & & \\
6 & Palm oil & 5 & 5 & 5 \\
7 & Sugar & 10 & 10 & 10 \\
8 & Crayfish & 5 & 5 & 5 \\
9 & Groundnut husk & 8 & 8 & 8 \\
\hline
\end{tabular}

Source: Asagba and Obi, 2005 (modified)

\section{Statistical Analysis of Data}

All data are expressed as mean $\pm S D$, unless specified otherwise. Comparison between the three rat groups were done using one way Analysis of Variance (ANOVA) and Fisher's protected least significant difference post-hoc testing. The mean values of the control and test groups were compared using the student's t-test, one tail analysis ${ }^{5}$. All statistical calculations were done using the SPSS version 22 statistical software package.

The average arsenic content of carbide treated banana fruits in Warri and its environ is represented in Table 1. There was a significant $(P<0.05)$ increase in the arsenic content of laboratory carbideinduced ripe banana (CTB-1) fruits when compared to the control. There was also an increase in the concentration of arsenic of market carbide-induced ripe banana (CTB-2) when compared with the control. 
The body weight changes and liver body weight ratios of rats exposed to arsenic level of market carbide-induced ripe banana (CTB-2) are presented in Table 2.

Table 2: Average arsenic content of carbide-treated banana fruits of Warri and environs

\begin{tabular}{clc}
\hline S/no & Treatment(s) & $\begin{array}{c}\text { Arsenic concentration (dry mass) } \\
\mathrm{Mg} / \mathrm{kg} \text { (mean } \pm \text { SEM) } \mathrm{n}=10\end{array}$ \\
\hline 1 & Control & $<0.001 \pm 0.00$ \\
2 & Laboratory induced & $0.18 \pm 0.01$ \\
& ripe banana(CTB-1) & $0.13 \pm 0.01$ \\
3 & Market induced & \\
& ripe banana(CTB-2) & \\
\hline
\end{tabular}

The effects of arsenic concentration of carbide-induced ripe banana are represented in Table 2. Carbide treated banana formulated feed (CTB-2), caused a slight increase $(P>0.05)$ in body weight change of the rat when compared to the control. There was a slight decrease $(P>0.05)$ in the liver body weight ratio of the rat when compared to the control (carbide and arsenic-free diet). There was also a significant $(P<0.05)$ decrease in bd. wt. change and an increase in arsenic- only treated diet when compared to the control.

The result of the effects of food chain mediated arsenic exposure on the plasma and tissue malondialdehyde level of the rat is presented in Table 3.

Table 3: Effects of food chain-mediated arsenic levels on body weight changes and liver body weight ratios

\begin{tabular}{ccc}
\hline Treatment(s)n & Body wt. change $(\mathrm{kg})$ & Liver/ bd. wt. ratio \\
\hline mean \pm SEM & mean \pm SEM $\times 10^{-2}$ \\
\hline Control & $8.30 \pm 0.25(5)$ & $31.20 \pm 2.38(5)$ \\
CTB-2 (4) & $9.10 \pm 0.50(4)$ & $30.70 \pm 2.05(4)$ \\
Arsenic only (5) & $5.50 \pm 0.40(5)$ & $43.80 \pm 2.90(5)$ \\
\hline
\end{tabular}

The effects of food chain mediated arsenic exposure on MDA levels is represented on Table 3. There were increases in plasma and liver malondialdehyde (MDA) levels of CTB-2 and arsenic only treated rats relative to the control. However, the increases were not significant $(P>0.05)$.

Table 4: Effects of food chain-mediated arsenic levels on malondialdehyde level of the rat

\begin{tabular}{lcc}
\hline & Plasma MDA \\
Treatment $(\mathrm{s})$ & \multicolumn{1}{c}{$\begin{array}{c}\text { Liver MDA } \\
\text { mean } \pm \text { SEM }\left(\times 10^{-3}\right)(\mathrm{n})\end{array}$} \\
\hline Control & $1.53 \pm 0.05(5)$ & $0.92 \pm 0.01(5)$ \\
CTB-2 & $1.96 \pm 0.08(4)$ & $1.15 \pm 0.05(4)$ \\
Arsenic only & $2.08 \pm 0.08(5)$ & $1.13 \pm 0.03(5)$ \\
\hline
\end{tabular}

The effects of food chain mediated arsenic exposure on alkaline phosphatases activities in the rat is presented in Table 4.

The effects of food chain arsenic exposure on plasma and liver alkaline phosphatases activities are represented in Table 4. There were significant $(P<0.05)$ increases in plasma and liver alkaline phosphatases activities of CTB-2 (group II) and arsenic only (group III) rat groups when compared with the control (group I).

Table 5: Effects of food chain-mediated arsenic exposure on alkaline phosphatases activities in the rat

\begin{tabular}{cccc}
\hline S/no & & $\begin{array}{c}\text { Plasma ALP } \\
\text { mean } \pm \text { SEM }\left(\times 10^{-3}\right)(\mathrm{n})\end{array}$ \\
& Treatment(s) & $10.35 \pm 1.20(5)$ & $3.28 \pm 0.14(5)$ \\
1 & Control & $20.18 \pm 1.63(4) \mathrm{a}$ & $5.31 \pm 0.18(4)$ \\
2 & CTB-2 & $25.96 \pm 1.30(5)$ & $5.93 \pm 0.10(5)$ \\
3 & Arsenic only &
\end{tabular}

DISCUSSION

The concentration of arsenic in the control and test diet is presented in Table1. After $72 \mathrm{~h}$ ripening duration period, the average concentration of arsenic obtained from the banana fruit was used to formulate feed in the laboratory and administered to the rats. Table 2 shows the body weight gain and organ bd wt. ratios of the rat after exposure to the formulated feed. Table 3 shows the effect of the feed on lipid peroxidation products (MDA levels) of exposed rats and Table 4 shows the effect of feed arsenic content on alkaline phosphatases activities.

Calcium carbide is considered a very hazardous toxin especially as a food processing agent because it contains traces of the heavy metal arsenic. ${ }^{18}$ Alteration in body and alteration in body weight is usually considered a toxicity index ${ }^{1,9}$. In this study, there was a slight decrease $(P>0.05)$ in liver body weight ratios of rats exposed to carbide treated banana (CTB) and a significant $(P<0.05)$ decrease in body weight of rats exposed to arsenic only via feed (Table 2).This could be as a result of elevated arsenic level detected in banana fruits treated with carbide when compared when compared with control. Our finding aligns with the report of ${ }^{4}$, who reported that calcium carbide was toxic since it contains traces of arsenic.

Study showed the ability of arsenite to activate protein synthesis ${ }^{13}$. Alkaline phosphatase concentrates in the liver and other organs. Although, 
some liver alkaline phosphatase activities are present in plasma. Elevation in plasma alkaline activities has been implicated in liver disease ${ }^{21}$. Observation of Table 4 of our present study showed a significant $(P<0.05)$ elevation in plasma alkaline phosphatases activities of CTB and arsenic only exposed rat group. This could be due to the ability of arsenic to induce the synthesis of alkaline phosphatase enzyme or cause liver injury with corresponding synthesis of the phosphatase enzyme. Our finding is in alignment with the report of ${ }^{13}$.

This study was undertaken to determine the arsenic concentration of banana fruits in Warri and environs. It was also undertaken to investigate if the arsenic concentration of the fruit considered in this study was significant enough to alter selected biochemical indices of toxicity. Our findings showed the possibility of carbide induced arsenic contamination of fruits and the possibility of arsenic concentration of fruits of Warri metropolis to alter the activities of alkaline phosphatases in plasma and cause a slight elevation in the product of lipid peroxidation.

\section{ACKNOWLEDGEMENT}

The authors are grateful for the financial support from the Petroleum Training Institute Effurun, a parastatal of the Federal Ministry of Petroleum Resources, Abuja, Nigeria.

\section{Conflicts of Interest}

The authors declare no conflict of interest.

\section{REFERENCE}

1. Asagba.S and Obi, F. O. (2005). A comparative evaluation of the biological effects of environmental cadmium-contaminated control diet and laboratory cadmium supplemented test diet. Biometals., 2005, 18, 153-161.

2. ATSDR (Agency for Toxic Substances and Disease Registry), "Comprehensive Environmental Response, Compensation and Liability Act (CERCLA)," Priority list of hazardous substances. U.S., 2011, http:// www.atsdr.cdc.gov/cercla.

3. Behari, JR and Prakash, R . Determination of total arsenic in samples by atomic absorption spectroscopy (AAS) using vapour generation assembly(VGA). Chemosphere.,2005, 63(1), 1721 doi 10:1016/j.chemosphere. 2005.07.073.

4. Dudley, R. Ethanol, fruit ripening and the historical origins of human alcoholism in primate frugivory. Integrated and Compositional Biolog., 2004, 4(4), 315-322.

5. Elzey, F.F. A programmed introduction to statistics. Second edition, California: Brooks/ Cole Publishing Company., 1971.

6. Emmanuel, I.N. , Nat, C.E., E. Anthony, C.E Paul,, V.E. Jude, R.E Tochukwu, E.E. Joseph. Effects on Hibiscus sabdariffa calyces on Serum cholesterol, Body weight and liver biomarkers of Rattus Noverjieus. Inter.J. IMP., 2013, 46, 4, ISSN: 2051-2062.

7. Garelick H, Jones H, Dybowska A, ValsamiJones E. Arsenic pollution sources. Rev Environ Contam Toxicol., 2008, 197,17-60.

8. Gutteridge JMC and Wilkins C. Copper dependent hydroxyl radical damage to ascorbic acid. Formation of thiobarbituric acid reactive products. FEBs Lett., 1982, 137, 327-340.

9. Horiguchi, H. M. Sato, N. Konno and M. Fukushima. Long Term Cadmium Exposure induces Ammonia in rats through hypo induction of erythropoietin in the kidneys. Arch. Toxicol., 1996, 71, 11-19.

10. IARC. Arsenic in drinking water. International Agency for Research on Cancer (IARC) Monographs., 2004, 84, 229.Retrieved from http://www.inchem.org/documents/iarc/ vol84/84-01-arsenic.html.

11. Kurzius-Spencer, M Burgess, JL., Harris, RB, Hartz, V., Roberge, J., Huang, S., Hsu Chiu-Hsieh, $\mathrm{H}$ and Rourke, MK. J. Expo Sci Env Epidemiol., 2014, 24(2), 156-162. Doi: 10.1038/jes2013.37

12. Lewis DR, Southwick JW, Ouellet-Hellstrom R, Rench J, Calderon RL. Drinking water arsenic in Utah: a cohort mortality study. Environ Health Perspect., 1999, 107, 359-365.

13. Ludwig S, Hoffmeyer A, Goebeler M.... "The stress inducer arsenite activates mitogenactivated protein kinases extracellular signalregulated kinases 1 and 2 via a MAPK kinase 6/p38-dependent pathway". The Journal of Biological Chemistry., 1998, 273 (4), 1917-22. doi:10.1074/jbc.273.4.191

14. Maclntosh DL, Spengler JD, Ozkaynak $H$, Tsai L, Ryan PB. Dietary exposures to selected metals and pesticides. Environ Health Perspect., 1996, 104, 202-209. 
15. Meacher MD, Menzel, DB., Dillencent, MD, Bic, L., Schoof, RA., Yost, LJ., Eickchoff, J and Farr, C.H. Estimation of multimedia inorganic arsenic intake in the U.S population. Human and Ecology Risk Assessment., 2002, 8(7), 1697-1721. DOI: 10.1080/20028091057565.

16. Medrano MA, Boix R, Pastor-Barriuso R, Palau M, Damian J, Ramis R,... Arsenic in public water supplies and cardiovascular mortality in Spain. Environ Res., 2010, 110, 448-454.

17. Meliker JR, Wahl RL, Cameron LL, Nriagu JO. Arsenic in drinking water and cerebrovascular disease, diabetes mellitus, and kidney disease in Michigan: a standardized mortality ratio analysis. Environ Health., 2007, 6, 1-11.

18. Mohammad, A. Physico-chemical properties and toxic effect of fruit-ripening agent calcium carbide. Annals of Tropical Medicine and Public Health., 2012, 5 (3), 150-156.

19. Naidu, R. Smith, E., Owens, G., Bhattacharya, $P$ and Nadebaum, P. Managing Arsenic in the Environment-From Soil to Human Health, CSIRO Publishing, and Melbourne., Australia., 2006.

20. Obi, F.O., and Fadairo, E. A. Influence of Anthocyanin-Free Aqueous Extract of Hibiscus sabdariffa, L Petal on Cadmium Toxicity in Male Rats. Nig. J. Life Sc., 2013, 3(1), 78-92.

21. Reiss I, InderriedenD, Kruse K. "Bestimmung der knochenspezifischen alkalischen Phosphatase bei Störungen des Kalziumstoffwechsels im Kindesalter". Monatsschrift Kinderheilkunde., 1996, 144 (9), 885-890.
22. Slayton, TM, Beck BD, Reynolds, KA, Chapnick SD, Valberg, PA, Yost IJ., Schoof, RA, Aucoin, R. Issue in arsenic cancer risk assessment. Environmental Health Perspect., 1996, 104, 1012-1018.

23. Varley, H. Practical Clinical Biochemistry, 4th Ed.Textbook of Medical Laboratory Technology. First Edition, Jaypee Brothers Medical publishers Ltd., New-Delhi 1975.

24. Walter, Kand Schutt, C. Methods of enzymatic analysis. 2nd edition, edited by Hans Uirich Bergmeyer and Walter Hiby., 1974 pages 856-860. Doi https://doi.org/10.1016/B9780-12-091302-2-x5001-4

25. WHO. Arsenic and Arsenic Compounds. Environmental Health Criteria., 2001, 224. Retrieved from http://whqlibdoc.who.int/ehc/ WHO_EHC_224.pdf.

26. Xue J, Zartarian V, Wang SW, Liu SV, Georgopoulos P. Probabilistic modeling of dietary arsenic exposure and dose and evaluation with 2003-2004 NHANES data. Environ Health Perspect., 2010, 118, 345-350.

27. Yost, L. J.; Tao, S.-H.; Egan, S. K.; Barraj, L. M.; Smith, K. M.; Tsuji, J. S.; Lowney, Y. W.; Schoof, R. A.; Rachman, N. J. "Estimation of Dietary Intake of Inorganic Arsenic in U.S. Children" (PDF). Human and Ecological Risk Assessment: An International Journal., 2004, 10 (3), 473-483. doi:10.1080/10807030490452151. ISSN 1080-703 